\title{
6
}

\section{RACE TO THE BOTTOM Constructions of asylum seekers in Australian federal election campaigns, 1977-2013}

\author{
Kathleen Blair
}

Issues pertaining to asylum seekers have long been the focus of negative political and public interest, with such interest intensifying in the lead-up to and throughout federal election campaigns. The 1977 federal election was the first in Australian history in which both major parties appealed to the public's unease about the arrival of asylum seeker boats. In fact, much of the anti-asylum seeker rhetoric to which Australians are now accustomed made its first appearance in the 1977 debates. However, the arrival of Vietnamese 'boat people' at that time became what analysts term a political 'non-issue'. ${ }^{1}$ It was not until the arrival of the MV Tampa, in August 2001, that the long-running debate on asylum seekers and refugees was brought to the fore in an election campaign and, arguably, impacted the election outcome. A tough approach to asylum seekers has been a feature of many federal election campaigns since, culminating in 2013 with the Liberal Party's now-infamous slogan, 'Stop the boats!', aptly summarising both government policy and public attitudes. This chapter

1 D Butler, 'Introduction', in The Australian National Election of 1977, ed. H R Penniman (Canberra: Australian National University Press, 1979), 15. 
explores the use of anti-asylum seeker sentiment in these three federal election campaigns, 1977, 2001 and 2013, and, in doing so, charts the origins of contemporary anti-asylum seeker discourse.

The arguments made by political leaders across the span of these four decades are remarkably similar, with political leaders borrowing from both their predecessors and their opponents. Contemporary concerns about 'economic refugees', 'queue jumpers' and 'illegals' are not unique to the twenty-first century. However, as the number of asylum seekers arriving by boat increased exponentially - approximately 2,000 asylum seekers arrived in the first wave from 1976 to 1979, compared to almost 45,000 between 2009 and 2013 - so too did the degree of cruelty in the government's efforts to dispel and exclude asylum seekers. The last two decades of Australian politics has seen both major political parties engaged in a 'race to the bottom', attempting to outdo one another with cruel and unusual punishments for those seeking Australia's protection.

\section{The first 'boat people' and the 1977 federal election}

On 27 April 1976, the Kien Giang arrived with the first Vietnamese asylum seekers on board. ${ }^{2}$ The five 'boat people' were issued with onemonth temporary visas the day after their arrival and were eventually granted permanent residence, without fuss. Neither the government nor the media paid much attention to their arrival. However, as more boats began to arrive, disquiet about asylum seekers grew among Australians. Community attitudes began to shift from indifference to widespread concern. ${ }^{3}$ Fears about the introduction of exotic diseases and the effectiveness of the authorities' surveillance of Australia's coastline grew louder, particularly when a boat was found to have reached Darwin unnoticed by the Australian military. ${ }^{4}$ Amid these increasing concerns, Prime Minister Malcolm Fraser announced that the 1977 federal election

2 Department of Immigration and Ethnic Affairs, Australia and Indo-Chinese Refugees, 1976-1980: A Chronology (Canberra: The Department of Immigration and Ethnic Affairs, 1981), 3.

3 L Riddett, 'The Gateway and the Gatekeepers: An Examination of Darwin's Relationship with Asia and Asians, 1942-1993', Journal of Australian Studies 19, (1995): 65-67, doi.org/10.1080/ 14443059509387237.

4 Klaus Neumann, Across the Seas: Australia's Response to Refugees: A History (Melbourne: Black Inc., 2015), 268-69. 
would be held on 10 December. While issues pertaining to refugees and asylum seekers were not hotly debated in the first few weeks of the campaign, political debate erupted on 21 November when six boats carrying 218 people arrived in Darwin in a single day. ${ }^{5}$

The Labor Party was quick to fuel the fears the public held about asylum seekers, attempting to use the issue of boat arrivals for electoral gain. Senator Tony Mulvihill, Labor's acting Immigration spokesperson, criticised the Fraser Government for its lack of 'selectivity on IndoChinese refugees', implying that at least some of the Vietnamese asylum seekers were not 'genuine'. ${ }^{6}$ Then Labor Party leader, Gough Whitlam, made a complementary argument when he questioned the legitimacy of Vietnamese 'boat people', arguing that 'genuine refugees' should be accepted (clearly insinuating that those arriving by boat were not genuine), but that the government should not put refugees 'ahead in the queue over people who have been sponsored and who are already coming here' 7 This imaginary queue, soon to become one of the most powerful images in the anti-asylum seeker discourse, served to distinguish between 'good' immigrants or refugees and 'bad' asylum seekers. ${ }^{8}$

Arguments about the 'genuineness' of refugees arriving by boat centred on their supposed wealth and the lack of an appearance of destitution. It was argued that some of the refugees were 'pseudo-refugees': 'they just don't look like refugees or people who have suffered or have had the trauma of that long trip.' 'The idea that people who were not visibly destitute and suffering could not possibly be refugees featured prominently in statements made by trade union officials and political leaders. ${ }^{10}$ Asylum seekers were consistently described as 'illegal immigrants', aspersions were cast on their 'moral fibre', and it was argued that they were not refugees because of their supposed wealth. ${ }^{11}$

5 Nancy Viviani, The Long Journey: Vietnamese Migration and Settlement in Australia (Melbourne: Melbourne University Press, 1984), 73-74.

6 Tony Mulvihill, 1977, quoted in Rachel Stevens, Immigration Policy from 1970 to the Present (New York: Routledge, 2016), 108-9.

7 'Hawke: Return Bogus Refugees', cited in Gerard Henderson, 'Girt by Sea: Correspondence', Quarterly Essay 6 (2002): 86.

8 Jane McAdam, 'Australia and Asylum Seekers', International Journal of Refugee Law 25 (2013):

435-48, doi.org/10.1093/ijrl/eet044.

9 Stack 1977, cited in Neumann, Across the Seas, 271.

10 Viviani, The Long Journey, 78-79; Neumann, Across the Seas, 270-76; Rachel Stevens, 'Political Debates on Asylum Seekers during the Fraser Government, 1977-1982', Australian Journal of Politics and History 58, no. 4 (2012): 530-532, doi.org/10.1111/j.1467-8497.2012.01651.x.

11 Neumann, Across the Seas, 270-76. 
The Labor Party were also intent on playing to a latent fear of invasion. Labor leaders urged the Fraser Government to 'make it clear that Australia is not going to open the floodgates ... We will have to try and find a way of showing our sympathy while stopping the flood of what basically are illegal immigrants. ${ }^{12}$ Labor used the arrival of Vietnamese asylum seekers to demonstrate their resolve to enforce Australia's immigration laws. Whitlam argued that Australia needed to increase its border enforcement policies to prevent unauthorised immigration, drug trafficking and the import of diseases, thereby associating asylum seekers with illegal activity and dangerous illnesses. ${ }^{13}$ To achieve this, he suggested buying new patrol boats to guard the Australian coastline. ${ }^{14}$ Mulvihill also called on the Fraser Government to 'make an example' of some of the unauthorised arrivals: 'We have to turn a few of them around and send them back to South-East Asia under naval escort'. ${ }^{15}$

In the 1977 election campaign, the Labor Party used several different arguments to cast doubt on the asylum claims of boat arrivals. Asylum seekers arriving by boat were portrayed as wealthy economic migrants attempting to 'jump the queue' by entering Australia without authorisation and they were unfavourably contrasted with 'legal' immigrants and 'genuine refugees'. ${ }^{16}$ Militarised and punitive responses, such as the turning back of boats and increasing border security, were proposed. Labor was intent on harnessing xenophobic sentiments and the public's fear of invasion for electoral gain.

The Liberal Fraser Government also used the arrival of asylum seeker boats to demonstrate to voters that they too could act tough on asylum seekers. On 16 November, the immigration department for the first time did not immediately grant entry permits to a group of asylum seekers and initially did not allow them to disembark their vessel. While the department issued them with visas 24 hours later, the initial refusal and an accompanying statement by Minister for Immigration Michael MacKellar, in which he announced that his department would urgently assess the implications of unauthorised entry, suggested the government was adopting a tougher approach. ${ }^{17}$ This 'tougher' approach was further

12 Quoted in 'Eighth Vessel on Way', 1977, cited in Neumann, Across the Seas, 270-71.

13 Stevens, 'Political Debates on Asylum Seekers', 530-32.

14 Stevens, Immigration Policy, 108-9.

15 Neumann, Across the Seas, 270-76.

16 Ibid., 270-76; Stevens, 'Political Debates on Asylum Seekers', 530-32.

17 Neumann, Across the Seas, 269. 
illustrated by statements made shortly after the arrival of the six asylum seekers boats on 21 November. Minister for Foreign Affairs Andrew Peacock said that Australia could not 'continue to indefinitely accept Asian refugees arriving unannounced by sea', and that 'Australia could not be regarded as a dumping ground' ${ }^{18}$ Fraser himself issued a warning that 'some Vietnamese who landed in Australia might have to be deported'. ${ }^{19}$ MacKellar reiterated this view by insisting that those who arrive by boat unannounced would not necessarily be allowed to resettle in Australia. ${ }^{20}$

While these statements from Fraser and MacKellar suggest a proposed escalation in border enforcement policies and resistance to the admission of authorised immigration, numerous examples also exist of a more 'compassionate' discourse in the 1977 campaign on behalf of the Liberal Party. For example, in the initial stages of the campaign, while Labor was quick to manipulate public concern over economic issues, drawing attention to the supposed economic consequences of accepting boat arrivals, MacKellar swiftly challenged these assertions. In response to Whitlam attempting to distort migrant employment figures, MacKellar stated:

It is surprising and unfortunate that Mr Whitlam should seek to make political capital out of the employment problems of the 20,000 refugees, evacuees and Lebanese who have sought sanctuary in Australia in the past 18 months ... These people have come to Australia mainly to survive and to build a new life out of the tatters of civil war and internal conflict in their former countries. The Fraser Government has seen this offer of sanctuary as the first priority. ${ }^{21}$

MacKellar consistently challenged the Labor Party's attempts to exploit the public's concerns over the economy and boat arrivals throughout the campaign. He dismissed allegations that rich migrants were posing as refugees to come to Australia, addressed concerns over the high levels of unemployment amongst new migrants by contextualising

18 'Peacock Warns', cited in Neumann, Across the Seas, 273.

19 'Fraser Warns Refugees', Sydney Morning Herald, 26 November 1977.

20 Stevens, Immigration Policy, 109.

21 Michael MacKellar, 1977, cited in Michelle Peterie, “"These Few Small Boats”: Representations of Asylum Seekers During Australia's 1977 and 2001 Elections', Journal of Australian Studies 40, no. 4 (2016): 446, doi.org/10.1080/14443058.2016.1223150. 
migrant unemployment as a normal stage in the settlement process, and highlighted Australia's responsibility to prioritise the safety of refugees and asylum seekers over one's ability to contribute to the nation's economy. ${ }^{22}$

MacKellar appeared intent on placating those anxious about boat arrivals and not allowing Labor to exploit the issue. However, he also seemed anxious not to appear too critical of those who expressed concern. He sought to balance the fears and anxieties of the electorate about border security with humanitarian concern: 'We have to combine humanity and compassion with prudent control of unauthorised entry or be prepared to tear up the Migration Act and its basic policies'. ${ }^{23}$ Like many ministers both before and after him, MacKellar emphasised the need for border control. However, he did not use this discourse to cultivate fear. Instead, he sought to justify the Fraser Government's policy of increasing Australia's refugee intake. For example, when MacKellar announced the decision to send immigration officials to Southeast Asia to process asylum seekers, he argued it was 'essential that entry to Australia was controlled' and that assisting the orderly international processing of refugees ... [would] avoid the need for genuine refugees to make the hazardous voyage to Australia'. ${ }^{24}$ MacKellar was keen to ensure that any action taken by his department was 'leavened with humanity and compassion for the plight of genuine refugees..$^{25}$

For much of the campaign, the Liberal Party's statements were merely reactive. They spoke out against the unfounded claims made by the Labor Party, challenging negative stereotypes as they began to gain momentum. However, less than two weeks before election day, the Fraser Government went on the offensive. In reference to Mulvihill's earlier statement, the two ministers committed their Liberal Government not to "'make examples" of boat refugees by indiscriminately turning some of them back', and not to 'risk taking action against genuine refugees just to get a message across', as doing so 'would be an utterly inhuman course of action'. ${ }^{26}$ Viewed through the lens of Australia's contemporary asylum seeker debate, these sentiments from the Liberal Party are remarkable. MacKellar's statements

22 Peterie, “"These Few Small Boats”, 444-46.

23 Neumann, Across the Seas, 273.

24 Michael MacKellar, 1977, cited in Peterie, “"These Few Small Boats”, 443.

25 Ibid., 443.

26 Joint statement by Andrew Peacock and Michael MacKellar, cited in Neumann, Across the Seas, 279. 
humanised those arriving by boat, portraying them as needy people who were deserving of help, and underlined Australia's legal and moral duty to respond to this 'human tragedy'.

The 1977 campaign exemplifies a contestation of power in which asylum seeker discourses were key. While the Labor Party attempted to convince voters that asylum seekers were 'bad' and that they should, therefore, vote for the party that would expel/reject them, the Liberal Party sought to do the opposite. The 1977 campaign was the first in Australian history in which the major parties appealed to the public's unease about unauthorised boat arrivals. The 1977 campaign was, however, also the first in which a senior government minister advocated a policy response to refugees that was not populist, and forcefully asserted the government's right and responsibility to pursue such a response. Despite their efforts, the Labor Party's attempts to make the arrival of boats a key election issue were unsuccessful; political scientists agree that the issue of boat arrivals did not influence the election outcome. ${ }^{27}$ When voters were asked to name the issues most important to them in the campaign, they nominated unemployment, inflation and economic management rather than immigration and border control. ${ }^{28}$ However, the language and arguments employed by political leaders to justify the exclusion of Vietnamese boat people introduced key phrases and ways of speaking about the arrival of 'boat people', many of which continue to influence contemporary debates on asylum seekers.

\section{The race to the bottom}

Since the first sustained arrival of asylum seeker boats, various policies have been enacted, slowly legalising and normalising the criminalisation and dehumanisation of people seeking asylum. Between 1989 and 1995, the second cohort of asylum seekers, mainly from South China and Cambodia, arrived. Concern over their uncontrolled and sporadic arrival saw the Hawke/Keating Labor Government establish laws for the (often prolonged) detention of asylum seekers arriving in Australia; in 1992 this detention become mandatory. Gerry Hand, then immigration minister, rationalised detention practices on the basis that it would deter prospective

27 Clem Lloyd, 'A Lean Campaign for the Media', in The Australian National Elections of 1977, ed. H Penniman (Washington: American Enterprise Institute for Policy Research, 1979), 246.

28 R K F, 'Australian Political Chronicle, July-December 1977: The Commonwealth', Australian Journal of Politics and History 24, no. 1 (1978): 75-80. 
asylum seekers. He was determined to send a clear signal 'that migration to Australia may not be achieved by simply arriving in this country and expecting to be allowed into the community'. ${ }^{29}$

Between 1996 and 2001, the third cohort of people seeking asylum, mainly from Iraq and Afghanistan, arrived. The then Liberal Howard Government introduced the practice of linking the nominal quota for the onshore and offshore programs. They also introduced the Border Protection Legislation Amendment Act 1999, which enabled immigration and customs officers to board, search and detain vessels in international waters. In October 1999, Temporary Protection Visas were introduced for asylum seekers arriving in Australia without a valid visa who were found to be refugees. ${ }^{30}$ These legislative measures were designed to protect humanitarian resettlement places for refugees who arrived in Australia via the humanitarian program or with a valid visa, thereby reinforcing the dichotomy between 'queue jumping' boat arrivals and 'genuine' refugees. Further, the government argued that temporary protection removed the incentive for asylum seekers to risk their lives at sea while still providing effective protection for those who continued to do so. However, the policy failed in these deterrence aims. The Australian Government had ignored the forces (e.g. persecution and war) that were driving Middle Eastern refugees to flee and seek asylum in Australia in the first place. As such, rather than declining, the number of asylum seekers arriving by boat increased dramatically. These increasing numbers culminated in late August 2001, bringing the issue of asylum seekers, for the first time, to the forefront of a federal election campaign.

\section{Border protection and the 2001 federal election}

Border protection was a major issue in the 2001 federal election and arguably determined its outcome. ${ }^{31}$ In 2001, Australia experienced enormous rises in asylum seeker boat arrivals - 5,516 arrived in 2001

29 Gerry Hand, 1992, cited in Stevens, Immigration Policy, 126.

30 Hossein Esmaeili and Belinda Wells, 'The "Temporary" Refugees: Australia's Legal Response to the Arrival of Iraqi and Afghan Boat People', UNSW Law Journal 23, no. 3 (2000): 224-45.

31 Ian McAllister, 'Border Protection, the 2001 Australian Election and the Coalition Victory', Australian Journal of Political Science 38, no. 3 (2003): 448, doi.org/10.1080/103611403200013398 5; David Marr and Marian Wilkinson, Dark Victory (Crows Nest: Allen \& Unwin, 2003). 
alone, almost double the year before. ${ }^{32}$ Securing Australia's border provoked more political and public attention as a result. Further, from late August onwards a series of events resulted in the issue of 'border protection' dominating much of the campaign. The two most significant events were the Tampa crisis and the related debate about how to deal with asylum seekers, and the September 11 terrorist attacks (9/11) in the United States and its implications for defence and foreign policy. Doubts put forward by politicians about the character of people seeking asylum in Australia were even more effective following these events. For the first six months of 2001, Labor had enjoyed a comfortable poll lead over the Liberals. ${ }^{33}$ However, support for the Labor Party began to dissipate after the Tampa crisis and 9/11. In the end, the party that won the 2001 election had promised to 'stop the boats'.

On 26 August, a Norwegian freighter, the MV Tampa, rescued 438 people seeking asylum whose boat began to sink while en route to Australia. On the grounds that the incident took place in Indonesian waters, the Australian Government refused the Tampa permission to enter Australian territory. After an extended debate and a stand-off lasting several days - in which the Tampa, with the 438 asylum seekers, merely floated off Australia's coast - a compromise was reached with New Zealand agreeing to take 150 of the asylum seekers. The remainder were sent to a hastily established processing centre on the Republic of Nauru, where their claims for protection were to be determined.

Throughout the 2001 election campaign, the Australian Government constructed the Tampa asylum seekers as a threat to national sovereignty and as antithetical to the Australian way of life. In doing so, Howard manufactured a shared Australian national identity built on the values of generosity and egalitarianism or 'a fair go'. These values were positioned as distinctly Australian and were defined through allusions to the asylum seeker. A key feature of Howard's portrayal of these Australian values was the assertion that they were under threat.

32 Janet Phillips and Harriet Spinks, 'Boat Arrivals in Australia since 1976' (background note, Department of Parliamentary Services, 2013), 22.

33 McAllister, 'Border Protection', 446; Ian McAllister, 'The Federal Election in Australia, November 2001', Electoral Studies 22 (2003): 382. 
A discourse of 'Australian generosity' towards migrants and refugees was crucial to Howard's construction of national identity. To demonstrate this generosity, Howard explicitly and repeatedly referred to the generosity of Australia's refugee program and highlighted Australia's reputation as a good international citizen:

Australia has a record in relation to caring for refugees of which every member of this House should be proud. No nation in the last 50 years has been more generous or more decent in relation to refugees than has Australia ... But that does not mean that we are abandoning in any way our right to decide who comes here; nor shall we ever abandon our right to refuse to allow people to be landed in this country ... ${ }^{34}$

Howard used the discourse of generosity to work up a positive image of Australians as 'open' to new arrivals, and conversely, a negative one of asylum seekers as threatening Australia's rights and national interest. This contrast acts as a disclaimer for Howard's subsequent assertion of sovereign rights, framing this as 'we are exercising our rights, but we are still generous'. In this conception, Australians are willing to welcome those who come through the right channels, with the right intentions, into the national space.

Political leaders also used the value of egalitarianism to present practices of exclusion and oppression as legitimate and to discredit asylum seekers as 'queue jumpers'. Political leaders used the 'queue' metaphor to represent the offshore immigration application system as a 'fair go' and asylum seekers arriving in Australia by boat as acting unfairly. ${ }^{35}$ Claims that people seeking asylum by boat should not be allowed into Australia were justified on the basis that they had 'jumped the queue' and were receiving unfair advantages over other migrants and refugees. 'Jumping the queue' is a violation of impartiality and fairness and effectively positions 'queue jumpers' as violating these central Australian values.

34 Danielle Every and Martha Augoustinos, 'Constructions of Australia in Pro- and Anti-Asylum Seeker Political Discourse', Nations and Nationalism 14 (2008): 571, doi.org/10.1111/j.1469-8129 .2008.00356.x.

35 See also Danielle Every and Martha Augoustinos, 'Constructions of Racism in the Australian Parliamentary Debates on Asylum Seekers', Discourse and Society 18 (2007): 411-36, doi.org/10.1177/ 0957926507077427; Carol Johnson, 'The 2002 Election Campaign: The Ideological Context', in The Centenary Election, ed. J Warhurst and M Simms (Brisbane: University of Queensland Press, 2002), 32-49; Peterie, “"These Few Small Boats"', 433-47. 
Political leaders drew on the idea of Australia as a generous and fair nation to construct and contrast two groups - 'fair Australians' and 'unfair asylum seekers. ${ }^{36}$ On the one hand, Australia was presented as kind and charitable and as having a deep-seated value to give a fair go to all. By implicit comparison, people seeking asylum by boat were positioned as unfair and anti-egalitarian, as morally antithetical to key Australian values and even as taking advantage of Australia's generosity. This positive/ negative contrast is a common strategy in anti-immigration discourses ${ }^{37}$ and, in this context, saw Australian values necessitate the rejection of asylum seekers. That is, to ensure the 'fair go' is maintained, Australia could not accept 'queue jumpers'.

The juxtaposition of these values functions to link inclusive and exclusive discourses. Howard consistently encouraged Australians to connect with a positive image of themselves as 'open' to new arrivals and effectively promised to safeguard 'Australianness' through the management and exclusion of potential threats to Australian values. ${ }^{38} \mathrm{He}$ gave voters permission to see their desire to manage immigration flows as a legitimate reaction to the threat presented by asylum seekers. Further, given that these discourses emerged in an election campaign, he emboldened voters to exercise their desire to manage immigration flows by voting for the political party that promised to do so.

The Australian public was largely supportive of Howard's response to the Tampa, reflecting both a history of opposition to new arrivals and increasing negative public sentiment. An Age poll found that 77 per cent of Australians agreed with Howard's decision to refuse the asylum seekers entry to Australia. ${ }^{39}$ NewsPoll also reported that 50 per cent of respondents believed that all boats should be turned back. ${ }^{40}$ Immediately following the incident, the Coalition received a 5 per cent increase in

36 Every and Augoustinos, 'Constructions of Australia', 574.

37 Teun van Dijk, 'Political Discourse and Racism: Describing Others in Discourse', in The Language and Politics of Exclusion: Others in Discourse, ed. S Riggings (London: Sage, 1997), 31-64.

38 Stephanie Younane Brookes, 'Exclusion and National Identity: The Language of Immigration and Border Control in Australian Federal Election Campaigns, 1903-2001' (paper presented at the Australian Political Science Association Conference, 2010).

39 Katharine Betts, 'Boat People and Public Opinion in Australia', People and Place 9, no. 4 (2001): $41-42$.

40 NewsPoll, 'Asylum Seeker Poll: 4/9/2001', Australian, available at: polling.newspoll.com.au/ image_uploads/cgi-lib.6364.1.010901asylum.pdf (site discontinued). 
the polls. ${ }^{41}$ Public support for the Howard Government increased even further after the September 11 terrorist attacks, with the Liberals achieving a 15 percentage point lead over Labor. ${ }^{42}$

The sense that the Tampa represented an attack on Australia, rather than a compounded tragedy for those aboard, continued to escalate through to the final days of the campaign. The Tampa affair and the government's subsequent response set the stage for the 2001 election campaign, in which the government both generated and capitalised on the public's unease toward asylum seekers, and foregrounded Howard's nowinfamous declaration: 'We will decide who comes to this country and the circumstances in which they come'. ${ }^{43}$

On 11 September 2001, two months before election day, a terrorist attack on the World Trade Centre Twin Towers and the Pentagon in the United States occurred, killing almost 3,000 people and injuring over 6,000 others, and triggering an international 'war on terror'. Within 48 hours of the terrorist attacks, and in an environment of suddenly and dramatically heightened concern over international terrorism, political leaders drew an explicit link between asylum seekers and terrorism. Defence Minister Peter Reith warned that the unauthorised arrival of boats 'can be a pipeline for terrorists to come in and use your country as a staging post for terrorist activities'. ${ }^{44}$ Howard cautioned: 'Australia had no way to be certain terrorists or people with terrorist links, were not among the asylum seekers trying to enter the country by boat from Indonesia'. ${ }^{45}$ Along with Reith, Howard was 'deliberately inflaming fear' by conflating the issue of asylum seekers with the newly emergent terrorist threat. ${ }^{46}$ These attacks and the Howard Government's subsequent response catalysed border protection and, by extension, asylum seekers as a crucial issue of the 2001 federal election campaign.

Even when direct relationships were not drawn, Howard and Ruddock's phrasing encouraged the association of asylum seekers with terrorism. In his policy launch speech, Howard constructed the arrival of asylum seekers

41 McAllister, 'Border Protection', 44.

42 McAllister, 'The Federal Election in Australia', 382.

43 John Howard, 'Liberal/National Coalition 2001 Federal Election Campaign Launch' (speech delivered at Sydney, NSW, 28 October 2001), Election Speeches, available at: electionspeeches. moadoph.gov.au/speeches/2001-john-howard.

44 'Australia Links Asylum Policy to US Attack', BBC News, 13 September 2001.

45 David Marr, Panic (Collingwood: Black Inc., 2011), 280-81.

46 Marr, Panic, 233. 
as an issue of 'national security' and spoke about the need for Australia to 'protect its borders' as 'a proper response to terrorism'. ${ }^{47}$ As Australia was then preparing for involvement in the US military campaign, the Howard Government's discussion of asylum seekers as a defence issue conflated them with the enemy of $9 / 11$. Howard highlighted the role of the Australian Defence Force (ADF) in intercepting boats, describing it as one of their most significant responsibilities, ${ }^{48}$ and effectively solidified the transformation of Australia's borders to a battlefront. Throughout the campaign, a border protection discourse was employed by Howard and his party to make the arrival of asylum seekers appear as a challenge to the physical safety of Australians, to Australian national identity and to national sovereignty. ${ }^{49}$ These constructions sought to reassure a concerned electorate that the government were doing whatever it took to prevent the arrival of the so-called threat.

The 'border protection' issue further fuelled the government's electoral advantage when, on 7 October, the Olong, a boat travelling to Australia from Indonesia with people seeking asylum, became the first to confront Operation Relex..$^{50}$ Official reports detail a series of events in which, after attempts to escort the vessel back to Indonesia, the Olong began to sink. Men, women and children, supported by life jackets, began jumping for their lives into the sea. The navy officers present assisted the 223 passengers to life rafts, diving into the water themselves to help the frightened passengers. This, however, was not the story the government told to the Australian public. Howard and Ruddock accused the asylum seekers of 'throwing their children overboard' in a 'premeditated' attempt to pressure the Australian authorities to rescue them. ${ }^{51}$ Images were released, proffered as 'absolute fact' that asylum seekers threw their children overboard when

47 Howard, 'Liberal/National Coalition 2001 Federal Election Campaign Launch'.

48 Peterie, “"These Few Smalls Boats”, 441.

49 Every and Augoustinos, 'Constructions of Australia', 574; Every and Augoustinos, 'Constructions of Racism', 530; Alison Saxton, “I Certainly Don't Want People Like That Here”: The Discursive Construction of "Asylum Seekers", Media International Australia 109, no. 1 (2003): 109-20, doi.org/ 10.1177/1329878x0310900111; Kieran O'Doherty and Martha Augoustinos, 'Protecting the Nation: Nationalistic Rhetoric on Asylum Seekers and the Tampa', Journal of Community and Applied Social Psychology 18 (2008): 576-92, doi.org/10.1002/casp.973.

50 Operation Relex is the name given to the ADF border protection operation conducted between 2001 and 2006. It formed part of the Howard Government's response to the Tampa incident and enabled the ADF to intercept, detain and turn back boats carrying asylum seekers.

51 Kate Slattery, 'Drowning Not Waving: The "Children Overboard” Event and Australia's Fear of the Other', Media International Australia 109 (2003): 93-108, doi.org/10.1177/1329878x0310900110; Ruddock quoted in Natalie O'Brien, 'Overboard Incident "Never Happened”', Australian, 12 July 2001. 
they were really images of adults and children fleeing their sinking vessel to save their lives. ${ }^{52}$ The government's claim that people seeking asylum had thrown their children overboard generated a media frenzy and further enabled the Howard Government to demonise asylum seekers.

Throughout the 2001 campaign, people seeking asylum were constituted as culturally different and incompatible with Australians. This negative discourse was emboldened after the 'Children Overboard Affair'. Campaigning in the aftermath of Tampa and 9/11, Howard described Australia's military support of the United States as a decision to 'defend the values we $\ldots$ hold dear'. ${ }^{53}$ Howard framed 'values' as a battleground and constructed those with different beliefs as the enemy. He created a benchmark of 'Australianness' and portrayed asylum seekers as the antithesis of the Australian 'us'. The Howard Government's portrayal of Australia as a decent country involved an emphasis upon family. Howard and Ruddock stressed Australia's morality by describing both the attention the navy paid to women and children during boat interceptions and the government's decision to house a number of women and children in 'alternative' detention facilities. ${ }^{54}$ Juxtaposing this representation of Australians as family people, in the aftermath of the 'Children Overboard Affair', asylum seekers were portrayed as abusers of children:

I can't comprehend how genuine refugees would throw their children overboard. I find that it is against the natural instinct, people leave a regime, leave a country, flee persecution to give a better life and to give a future to their children. Not to put it at risk. $^{55}$

While these threats to children were baseless, the stories told by government ministers portrayed asylum seekers as inhumane, barbaric 'others' who did not possess basic human qualities of parental devotion. Further, he reserved the qualities of humanity and morality for Australians, condemning asylum seekers not only for their violation of Australian ideals but for their violation of 'natural instinct'. In stark contrast to MacKellar's representation of asylum seekers in 1977, in which he suggested that

52 Reith quoted in O'Brien, 'Overboard Incident'.

53 Howard, quoted in Peterie, “"These Few Small Boats”, 438.

54 Peterie, “"These Few Small Boats”, 440.

55 John Howard, 'Press Conference Melbourne' [interview transcript], PM Transcripts, Department of Premier and Cabinet, 8 October 2001, available at: pmtranscripts.pmc.gov.au/release/transcript-12104. 
Australia's humanity would be jeopardised if asylum seekers were not treated well, Howard and Ruddock cast doubt upon the humanity of asylum seekers, effectively dehumanising them.

Howard's campaign against asylum seekers, together with the events of 9/11, was instrumental to his re-election. As Ian McAllister's analysis of the 2001 Australian Election Study (AES) shows, almost one in four voters mentioned refugees and asylum seekers, defence or terrorism as their major election concern, with the Coalition being, by far, the most preferred party to handle these issues. ${ }^{56}$ In contrast to the 1977 election, which saw MacKellar attempt to humanise and contextualise Australia's boat arrivals, in 2001 the Howard Government condemned people seeking asylum for not having progressed through the appropriate resettlement channels and constructed them as undeserving outsiders that posed a threat to Australia's sovereignty, safety and identity. The Howard Government's fervent campaigning on 'border protection' 'clearly manipulated the circumstances of people seeking asylum for electoral gain ${ }^{57}$ and, in doing so, paved the way for the campaigns conducted by the Liberal Party under the leadership of Tony Abbott in 2010 and, again, in 2013.

\section{The 2013 federal election: Stopping the boats}

The fourth cohort of boats, between 2009 and 2013, saw by far the largest number of asylum seekers reach Australian shores - almost 45,000 over five years; 30,000 of which arrived in $2012-13 .{ }^{58}$ For the three years prior to the 2013 election, as the number of arrivals continued to increase, then-leader of the Liberal Party Tony Abbott engaged his party in a longstanding campaign that was largely responsible for focusing the public and media's attention on the arrival of people seeking asylum - keeping this issue at the top of the political agenda. While Australians have long

56 McAllister, 'Border Protection', 451.

57 Senate Select Committee on a Certain Maritime Incident, Report of the Senate Select Committee

on a Certain Maritime Incident (Canberra: Parliament of Australia, 2002), 478.

58 Phillips and Spinks, 'Boat Arrivals in Australia since 1976', 22. 
expressed disdain for the arrival of people seeking asylum, ${ }^{59}$ the Liberal Party's emphasis on this issue saw it increase in importance to voters. The 2010 AES reports that, when asked how important the issue of asylum seekers and refugees was, 37 per cent of voters stated it was 'extremely important' to them. ${ }^{60}$ This increased to 46 per cent in $2013^{61}$ (close to the 50 per cent of voters who felt the same way in 2001). ${ }^{62}$ The majority of respondents ( 41 per cent) also believed the Liberal Party's policies were closest to their own views on this issue - only 19 per cent of respondents felt the same way about the Labor Party. Both major parties capitalised on this issue in the 2013 federal election campaign, attempting to outdo each other in terms of introducing tough asylum seeker policies and, in turn, win the support of the voting public.

On 19 July 2013, two weeks before the official federal election campaign was announced, and three weeks after regaining leadership of the Labor Party by disposing Julia Gillard as prime minister, Kevin Rudd announced a Regional Resettlement Arrangement between Australia and Papua New Guinea, stating: 'As of today, asylum seekers who come here by boat without a visa will never be settled in Australia'. ${ }^{63}$ These remarks were unprecedented. Neither side of politics had ever stated that asylum seekers identified as refugees would be permanently denied resettlement in Australia. Rudd acknowledged it was a 'hard-line' decision, but argued that 'our responsibility as a Government is to ensure that we have a robust system of border security and orderly migration' ${ }^{64}$ Despite this policy announcement and a subsequent announcement of a similar deal with the nation of Nauru, the Labor Party did not actively seek to promote their new-found policy stance. During the 2013 campaign, the Labor

59 See for example, Murray Goot and Ian Watson, Population, Immigration and Asylum Seekers: Patterns in Australian Public Opinion (Canberra: Department of Parliamentary Services, 2011); Ian McAllister and Sarah Cameron, Trends in Australian Political Opinion: Results from the Australian Election Study, 1987-2013 (Canberra: Australian National University, 2014); Betts, 'Boat People and Public Opinion', 41-42.

60 Ian McAllister, Clive Bean, Rachel Kay Gibson and Juliet Pietsch, Australian Election Study, 2010 (Canberra: Australian National University, Australian Data Archive, 2011).

61 Clive Bean, Ian McAllister, Juliet Pietsch and Rachel Kay Gibson, Australian Election Study, 2013 (Canberra: Australian National University, Australian Data Archive, 2014).

62 Clive Bean, David Gow and Ian McAllister, The 2001 Australian Election Study (Canberra: Australian National University, Australian Data Archive, 2007).

63 Bianca Hall and Jonathan Swan, 'Kevin Rudd to Send Asylum Seekers Who Arrive by Boat to Papua New Guinea', Sydney Morning Herald, 19 July 2013.

64 Ibid. This policy position was a reversal of the position Rudd took when first coming into office in 2007. Within two months of his first prime ministership Rudd had abolished Howard's Pacific Solution and those asylum seekers who had been sent to Nauru were brought to Australia. 
Party focused on 14 broad election policy pledges that did not refer to 'asylum seekers', 'boats' or 'borders' ${ }^{65}$ Labor's policy to support offshore processing and the settlement of asylum seekers in Papua New Guinea was aimed at shutting down debate on an issue that was a Coalition strength. ${ }^{66}$ It could be assumed that the policy position they took and the limited campaigning they did on this issue was out of a desire to neutralise the issue while trying to attract or retain voters sympathetic to the Coalition's position.

In stark contrast to the Labor Party, the Coalition wittingly pursued the asylum seeker issue and, with the news media, effectively raised its prominence as an election issue. ${ }^{67}$ Abbott's Liberal Party, like their predecessors, recognised political advantage in campaigning on asylum seeker boat arrivals. Within one week of Labor's policy announcement, the Liberal Party responded by releasing their official 'Operation Sovereign Borders' policy proposal, promising to 'stop the boats' by taking even tougher action on people seeking asylum. ${ }^{68}$ Liberal policy was primarily framed in terms of border protection and national security. They promised a military-led operation against 'illegal arrivals', consistent with the punitive position of former prime minister John Howard. The Coalition identified 'border protection' as an election priority in their 12-point 'Real Action' plan and again in their shortened six-point plan, which included a pledge to 'deliver stronger borders' and 'stop the boats'. In less than a month they released three policy documents: The Coalition's Operation Sovereign Borders Policy, The Coalition's Policy to Clear Labor's 30,000 Border Failure Backlog and The Coalition's Policy for a Regional Deterrence Framework to Combat People Smuggling, cementing not only their commitment to 'protecting Australia's borders' but also asylum seekers as a key election issue.

65 'Australian Labor Campaign Media: Media Releases and Transcripts' [data resource], Pandora, National Library of Australia, viewed 3 October 2017, available at: pandora.nla.gov.au/ pan/22093/20130906-0237/www.alp.org.au/campaign_media.html.

66 See Sara Dehm and Max Walden, 'Refugee Policy: A Cruel Bipartisanship', in Double Disillusion: The 2016 Australian Federal Election, ed. A Gauja, P Chen, J Curtin and J Pietsch (Canberra: ANU Press, 2018), doi.org/10.22459/dd.04.2018.26, for a discussion of the impact of this political bipartisanship in the 2016 election.

67 Andrea Carson, Yannick Dufresne and Aaron Martin, 'Wedge Politics: Mapping Voter Attitudes to Asylum Seekers Using Large-Scale Data During the Australian 2013 Federal Election Campaign', Policy and Internet 8, no. 4 (2016): 478-98, doi.org/10.1002/poi3.128.

68 Liberal Party of Australia and the Nationals, The Coalition's Operation Sovereign Borders Policy (Barton: Liberal Party of Australia and the Nationals, 2013). 
In the 2013 campaign, Abbott's Liberal Party emulated the arguments made by Howard and his government in 2001, actively demonising and dehumanising people seeking asylum by boat. Political candidates, ranging from shadow ministers to future backbenchers, adopted a threat discourse, emphasising that Australia needed to strengthen and secure its borders. The arrival of asylum seeker boats was framed yet again as an affront to Australian sovereignty and safety and security, with political leaders linking these issues, where possible, to broader social issues.

Controlling the arrival of asylum seekers and refugees emerged as an important theme, with both the Coalition and Labor emphasising the importance of determining and controlling what type of people came to Australia and how they arrived. The Coalition's endorsement of this notion of control was cemented in Howard's infamous campaign speech in the 2001 campaign. In the 2013 campaign, there were several instances in which Coalition politicians and policy documents directly quoted this speech when discussing their promise to 'stop the boats'. All three policy documents variously stated:

It was Prime Minister John Howard who declared that 'we will decide who comes to this country and the circumstances in which they come'. This was a statement of national sovereignty which underlined the need for Australia to control our borders. A Coalition government will restore real policies that live up to this declaration. This is our country and we will decide who comes here. ${ }^{69}$

The Coalition's consistent references to Howard's words served to not only cement their current commitment to protecting the Australian people but also functioned as a reminder that they had never wavered in this commitment and had successfully protected it in the past.

Throughout the campaign, Liberal Party candidates were consistent in referencing the perceived shortcomings of the Labor Government regarding border protection, drawing comparisons between the increased number of boat arrivals that occurred under the Rudd/Gillard government and the relatively few arrivals under the preceding Howard Government.

69 Liberal Party of Australia and the Nationals, The Coalition's Policy for a Regional Deterrence Framework to Combat People Smuggling (Barton: Liberal Party of Australia and the Nationals, 2013), 7. 
Labor's border failure is the consequence of Labor's failed policies and failed resolve. Labor weakened Australia's borders by abolishing the proven border protection policy regime established by the Howard Government and has provided an open invitation to the people smugglers through their six years in office. ${ }^{70}$

Again, this reference to the 'Howard era' served a strategic purpose. Candidates typically want their electorate to make voting choices using criteria that are based on dimensions favourable to themselves; thus, candidates will often raise issues that they or their affiliated party are seen to be the 'owners' of. Issue ownership posits that the longstanding parties hold reputations for their ability to handle certain issues. ${ }^{71}$ These reputations, in turn, provide candidates with credibility over issues associated with their party. By increasing the salience of party-owned issues, the Liberal Party was able to stack the campaign agenda with issues that emphasised their strengths while simultaneously highlighting their opponent's weaknesses.

Unlike in 2001 when the government was forced to deal with events that kept the asylum seeker issue in the public eye, in 2013, aside from the continued arrival of boats, no such events occurred. As such, the Coalition attempted to manufacture concern and interest by focusing on the increased number of arrivals and exaggerating the issues associated with this influx:

This is a national emergency. When you've had almost 50,000 illegal arrivals by boat, you have a crisis on your borders; and in the end, the first responsibility of government is national security. If you don't control your borders, to that extent, you are losing sovereignty over your own nation. ${ }^{72}$

The Coalition used the increased number of arrivals to construct asylum seekers as a threat to the national interest and the so-called integrity of Australian borders. The issue of protecting and securing/resecuring Australia and its border was a core component of the Coalition's campaign. One of the Coalition's key campaign promises was to deliver a 'safe, secure

70 Liberal Party of Australia and the Nationals, Operation Sovereign Borders Policy, 3.

71 David Damore, 'The Dynamics of Issue Ownership in Presidential Campaigns', Political Research Quarterly 57, no. 3 (2004): 391-97, doi.org/10.2307/3219849.

72 'Tony Abbott Transcript - Joint Press Conference' [press conference transcript], Liberal Party of Australia, 2013, available at: members.nsw.liberal.org.au/tony-abbott-transcript-joint-press-conferencebrisbane (site discontinued). 
Australia'. This promise of safety and security was then aligned with the ubiquitous promise of 'stopping the boats'. The Coalition effectively framed the arrival of asylum seekers as a threat, communicating that Australia could not be safe or secure while asylum seeker boats continued to arrive on Australian shores. In contrast to the 2001 campaign, in which explicit links were drawn between the arrival of people seeking asylum by boat and the threat of international terrorism, the 2013 campaign saw both major parties engage in this rhetoric in a more discreet manner. It could be argued that explicit statements that constructed asylum seekers as a threat to national safety were no longer necessary as this narrative was already so embedded in public opinion.

The Coalition's representation of asylum seekers was also determinedly militaristic. Terminology such as 'military-led response', 'tactical responses', 'targeted military operation' and even 'Operation Sovereign Borders' explicitly connected people seeking asylum by boat to the Australian defence forces. The use of this terminology in conjunction with the exaggerated language of 'border protection crisis' and 'national emergency' sought to prime the electorate into a state of concern over boat arrivals, with the militaristic language reinforcing the severity of this issue and, ultimately, justifying the government's proposed response.

Another function of the asylum seeker discussion that is more subtle, but in its own way more profound, is how the number of boat arrivals is amplified, not because of its intrinsic qualities as a threat to sovereignty and border security, but because of its usefulness as a broader political proxy. The primary issue the 2013 campaign revolved around was the management of Australia's economy. While Rudd focused on Australia's AAA rating and how his government overcame the global financial crisis, Abbott emphasised the size of Labor's debt and deficit in comparison to the preceding Howard Government. While these issues were largely spoken about as separate to asylum seekers and border control, the Coalition conflated the two by discussing the costs associated with the increased boat arrivals:

Between 2007-08 and 2013-14, the budget for managing illegal boat arrivals has blown-out by $\$ 10.3$ billion. This is real money that could have been spent on Australian schools, hospitals or improving our infrastructure. ${ }^{73}$

73 Liberal Party of Australia and the Nationals, Operation Sovereign Borders Policy, 3. 
The Liberal Party sought to use the asylum seeker issue as a proxy for the broader concerns of the electorate. Issues of diminished access to education and healthcare, underfunded infrastructure and unaffordable housing etc. all created fertile ground for a national debate by shadow play and proxy, whereby asylum seekers were framed as placing additional strain on already depleted resources and government services.

The construction of asylum seekers as a threat to resources was also prominent in local-level campaigning. Various candidates attempted to localise their party's national campaign by drawing on real concerns of their electorate and framing the arrival of asylum seeker boats as a challenge to said issues. A prominent example of this was when Liberal candidate Fiona Scott related asylum seekers to issues of traffic congestion and hospital waiting times:

It's [asylum seekers] a hot topic here because our traffic is overcrowded.

My recommendation is go and sit in the emergency department of Nepean hospital or go and sit on the M4, and people see 50,000 people come in by boat, that's more than twice the population of Glenmore Park. ${ }^{74}$

Political candidates skirted over important electoral issues and used asylum seekers as either a scapegoat or deflection to avoid addressing these problems. In doing so, they created a sense of unfair imposition by framing the influx of boat arrivals as responsible for one's economic struggles; political leaders both generated and capitalised on these feelings of deprivation at the hand of the asylum seeker, effectively communicating to their constituents that the easiest way to solve these problems was to 'stop the boats'.

One of the most notable features of the rhetoric on asylum seeker boat arrivals throughout the 2013 campaign was the reticence of political leaders to use categories such as asylum seekers or refugees to describe this group. Rather, political leaders consistently used variations of the more ideologically loaded 'illegal boat arrivals'. This language depicts asylum seekers who arrive in Australia by boat as illegitimate and, more seriously, as criminal. It is important to note also that, by referring to this group as

74 Fiona Scott, 'Liberal Candidate Fiona Scott Links Asylum Seekers to Traffic Jams', ABC News, 2 September 2013, available at: www.youtube.com/watch?v=y9i9OQHkpOM. 
illegal boat arrivals, as opposed to asylum seekers or refugees, political leaders sought to sever the linguistic reminder that these people are in fact seeking safety and protection. Instead, this choice of terminology disconnects them from the reasons for seeking asylum and delegitimises their legal entitlements and rights, while simultaneously criminalising their actions and positioning them as a threat. This construction again served to justify and necessitate the government's and opposition's 'hard-line' policies.

In contrast, the term 'genuine' was used to describe those refugees processed overseas and later resettled in Australia. The construction of these two distinct groups, 'genuine refugees' and 'illegal boat arrivals', served to reinforce the illegitimacy of the latter:

More than 14,500 desperate people have been denied a place under our offshore humanitarian programme because those places have been taken by people who have arrived illegally by boat. These people are genuine refugees, already processed by United Nations agencies, but they are denied a chance of resettlement by people who have money in their pocket to buy a place via people smugglers. ${ }^{75}$

The dichotomous categories of 'illegal boat arrivals' and 'genuine refugees' were determined through discussions on the mode of arrival of asylum seekers, the notion of a 'queue' and the wealth of irregular arrivals, thus creating implicit criteria used to delineate between illegitimate and undeserving asylum seekers and legitimate and deserving refugees.

The frameworks developed by the Coalition in response to the various events that occurred throughout 2001 proved crucial to the Coalition's 2013 campaign. However, unlike the 2001 election, in which people seeking asylum by boat were explicitly connected to terrorism, had their morality questioned and were positioned as being at odds with Australian values, the 2013 campaign saw these themes emerge much more obscurely. These concerns/fears were already so salient among the population that political leaders no longer needed to draw these explicit connections, they just needed to gently remind the public that these anxieties were still valid.

75 Liberal Party of Australia and the Nationals, Operation Sovereign Borders Policy, 3. 


\section{Conclusion}

Despite Australia's history of refugee resettlement, opposition to people seeking asylum has always existed and has often been the dominant discourse. While the events of 2001 mark a significant change in Australia's refugee history, much of the way we talk about asylum seekers began in 1977. Constructions of asylum seekers as 'illegal', 'queue jumpers' and as a threat to Australia's sovereignty and security have been in circulation since the very first cohort of 'boat people'. Political leaders have since borrowed and built on the language and policies of both their predecessors and their opponents, strategically tailoring their arguments to the 'threat of the day'. Constructions of asylum seekers as criminals in the late 1970s emerged once again in 2001 and were reappropriated after the events of 9/11 in which asylum seekers were then portrayed as terrorists. This discourse proved so pervasive that by 2013 political leaders merely needed to remind their constituents of the supposed security imperatives of increased boat arrivals. ${ }^{76}$

Political leaders have consistently used (or at least attempted to use) the respective increase in boat arrivals to their electoral advantage. While this was not as effective in the 1977 campaign as it was in 2001 and 2013, the debates that emerged set a precedent for future discussions about asylum seekers. The misrepresentation of asylum seekers as illegitimate and the use of this issue as a proxy for other electoral issues proved useful for political parties seeking electoral gain. As such, in pursuit of public support, both major political parties have been engaged in a 'race to the bottom', ensuring that the rhetoric they use and the policies they introduce are tougher than their opponents.

76 Sara Dehm and Max Walden's analysis of the 2016 election reveals yet again the pervasiveness of the construction of people seeking asylum as threats to Australia's security and identity in political discourse: see Dehm and Walden, 'Refugee Policy: A Cruel Bipartisanship'. 
This text is taken from Refugee Journeys: Histories of Resettlement, Representation and Resistance, edited by Jordana Silverstein and Rachel Stevens, published 2021 by ANU Press, The Australian National University, Canberra, Australia.

doi.org/10.22459/RJ.2021.06 